\title{
THE DISTRIBUTION OF TP53 GENE POLYMORPHISMS IN CHRONIC LYMPHOCYTIC LEUKEMIA PATIENTS, SUFFERERS OF CHORNOBYL NUCLEAR POWER PLANT ACCIDENT
}

\author{
N.I. Bilous*, I.V. Abramenko, A.A. Chumak, I.S. Dyagil, Z.V. Martina \\ State Institution "National Research Center for Radiation Medicine, \\ National Academy of Medical Sciences of Ukraine”, Kyiv 04050, Ukraine
}

\begin{abstract}
Previous analyses in a cohort of Chornobyl cleanup workers revealed significantly increased radiation-related risk for all leukemia types, including chronic lymphocytic leukemia (CLL). Numerous investigations emphasized the significance of genetic susceptibility to the radiation carcinogenesis. The aim of the work was to study the distribution of TP53 single nucleotide polymorphisms (SNPs) in CLL patients exposed to ionizing radiation (IR) due to Chornobyl nuclear power plant accident and estimate their impact on disease development. Materials and Methods: The TP53 exonic and intronic SNPs were analyzed in 236 CLL patients by polymerase chain reaction and direct sequencing. The main group included 106 IR exposed CLL patients and the control group was composed of 130 IR non-exposed CLL patients. Results: Nineteen TP53 SNPs were found in the observed CLL cohort. No significant differences were found between the main and the control groups, but increased frequencies of T/T rs12947788 + G/G rs12951053 homozygotes and rs146340390 C/T variants were found among IR-exposed CLL patients compared with healthy Europeans (data from the 1000 Genomes Project). Rare nucleotide substitution rs146340390 (c.665C $>$ T) was found only in the main group. These features were primarily typical for the most affected group of IR-exposed patients, namely, cleanup workers engaged in emergency works in the $2^{\text {nd }}$ quarter of 1986. Conclusion: These preliminary findings don't contradict the assumption on possible influence of IR on CLL development via the p53-dependent pathway. This article is a part of a Special Issue entitled "The Chornobyl Nuclear Accident: Thirty Years After".
\end{abstract}

Key Words: chronic lymphocytic leukemia, TP53 gene, polymorphism.

Previous analyses in the cohort of Chornobyl cleanup workers revealed significant radiation-related increased risk for all leukemia types, including chronic lymphocytic leukemia (CLL) [1-3]. Further study did not find additional effects of occupational and lifestyle factors on CLL risk in this radiationexposed cohort [4]. Numerous investigations emphasized the significance of genetic susceptibility to the development of tumors after exposure to carcinogens [5-7]. Considering the role of TP53 as a key tumor suppressor, intensive search of its cancer susceptibility allelic variants have been conducted. The TP53 codon 72 G/C (Arg72Pro) polymorphism (rs 1042522) is the most studied single nucleotide polymorphism (SNP) that might be associated with the risk of acute lymphoblastic leukemia [8], breast cancer [9], cervical cancer and papillary thyroid carcinoma (in combination with pri-miR-34b/c rs4938723) [10, 11], digestive tract cancers in Asians [12], etc. Another studied TP53 SNPs included rs78378222 (associated with basal cell carcinoma, prostate cancer, glioma, and colorectal adenoma [13]), rs12947788 and rs12951053 (associated with asbestos-exposed non-small cell lung cancer [14]), rs1042522,

Submitted: August 1, 2016.

*Correspondence: Fax: (044) 483-72-40

E-mail: nbilous@yahoo.com

Abbreviations used: CLL - chronic lymphocytic leukemia; $\mathrm{d}$ - differences between expected and observed allele frequencies; IGHV - immunoglobulin heavy chain; HWE - Hardy - Weinberg equilibrium; IR - ionizing radiation; MAF - minor allele frequency; SNP - single nucleotide polymorphism. rs17878362, and rs1625895 (associated with diffuse large B-cell lymphoma [15]), rs17878362 (associated with breast and colorectal cancer [16]). Only two TP53 SNPs (rs1042522 and rs 17878362) were analyzed in CLL patients up-to-date [17-19]. Thus, the aim of the work was to study the distribution of TP53 SNPs in CLL patients exposed to ionizing radiation (IR) due to Chornobyl nuclear power plant accident and clarify their impact on the disease development.

\section{MATERIALS AND METHODS}

The TP53 exonic and intronic polymorphisms were analyzed in 236 CLL patients, 196 males (83.1\%) and 40 females $(16.9 \%)$, with median age of 58 years at the moment of CLL diagnosis, referred to the State Institution "National Research Centre for Radiation Medicine of the National Academy of Medical Sciences of Ukraine", Kyiv, Ukraine. All patients were Caucasians from the central part of Ukraine. The study was approved by the local Ethics Review Committee, and all patients signed an informed consent form prior to participation in the study. CLL was diagnosed on the basis of clinical history, lymphocyte morphology, and immunophenotypic criteria. The stage of the disease was assessed by Binet [20] and Rai classification [21].

Patients were distributed into two groups according to IR exposure. The main group included 106 IR exposed CLL patients and the control group included 130 IR non-exposed CLL patients. The group of IRexposed CLL patients included 83 cleanup workers (in particular, 72 cleanup workers of 1986), 16 inhabit- 
ants of radionuclide contaminated areas, and 7 evacuees. Patients of the two groups were of comparable age, CLL stage at diagnosis, mutational status of immunoglobulin heavy chain (IGHV) genes (Table 1).

Table 1. Baseline clinical characteristics of observed CLL patients

\begin{tabular}{lccc}
\hline \multicolumn{1}{c}{ Characteristics } & $\begin{array}{c}\text { IR-exposed pa- } \\
\text { tients, } \mathrm{n}=106^{\star}\end{array}$ & $\begin{array}{c}\text { Control group, } \\
\mathrm{n}=130^{\star}\end{array}$ & p value \\
\hline Median age, years (range) & $57(39-76)$ & $58(33-77)$ & 0.714 \\
Sex, $\mathrm{n}(\%)$ & & & 0.015 \\
Male & $95(89.6)$ & $101(77.7)$ & \\
Female & $11(10.4)$ & $29(22.3)$ & \\
Rai stage at diagnosis, $\mathrm{n}(\%)$ & & & 0.532 \\
O & $13(12.3)$ & $18(13.8)$ & \\
I & $35(33.0)$ & $47(36.2)$ & \\
II & $48(45.3)$ & $49(37.7)$ & \\
III & $5(4.7)$ & $12(9.2)$ & \\
IV & $5(4.7)$ & $4(3.1)$ & \multirow{2}{*}{0.259} \\
Binet stage at diagnosis, $\mathrm{n}(\%)$ & $50(47.2)$ & $66(50.8)$ & \\
A & $49(46.2)$ & $49(37.7)$ & \\
B & $7(6.6)$ & $15(11.5)$ & \multirow{2}{*}{0.345} \\
C & & & \\
IGHV mutational status, $\mathrm{n}(\%)$ & $36(34.6)$ & $36(28.8)$ & \\
Mutated & $68(65.4)$ & $89(71.2)$ & \\
Unmutated & &
\end{tabular}

Note: ${ }^{*} / G H V$ mutational status was evaluated in 104 and 125 patients of IR-exposed and control groups, respectively.

Genomic DNA was extracted from peripheral whole blood samples with the QIAamp Blood Mini Kit (Qiagen, Crawley, UK) according to the manufacturer's protocol. TP53 genotyping was performed for 3-10 exons and adjacent introns by PCR amplification followed by direct sequencing as described earlier [22]. Obtained data were validated using the IARC TP53 Mutation Database (http://p53.iarc.fr/) and dbSNP database (http://www.ncbi.nlm.nih.gov/SNP). The Hardy Weinberg equilibrium (HWE) was evaluated using the chi-square $\left(X^{2}\right)$ test for all revealed SNPs. The frequencies of SNPs in the main and the control groups were compared by $\chi^{2}$ test. The SNP frequencies obtained in the analysis were compared by Brandt - Snedecor method or $\chi^{2}$ test with the data from the $1000 \mathrm{Ge}$ nomes Project (http://www. 1000genomes.org/). Linkage disequilibrium of SNPs was determined based on $d$ estimates (differences between expected and observed allele frequencies) using CubeX online program (http://www.oege.org/software/cubex/). All tests were two-sided and considered to be statistically significant with a $p$ value of $\leqslant 0.05$. Statistical analysis was performed using the SPSS 16.0 software package (SPSS, Chicago, IL).

\section{RESULTS AND DISCUSSION}

Nineteen TP53 SNPs were found in the observed CLL cohort. The distribution of SNPs, minor allele frequency (MAF) and concordance with HWE are presented in Table 2. No significant differences were found between the main and the control groups.

Only two SNPs (rs12947788, and rs12951053) showed evidence $(p<0.05)$ of deviation from HWE due to increased number of minor homozygotes ( $T / T$ and $G / G$, respectively), especially in the main group (Fig. 1). The frequencies of $T / T$ rs 12947788 , and G/G rs 12951053 genotypes in the main group were higher than these among healthy Caucasians (Table 3). Similar results were reported by Andujar et al. [14] for
Table 2. Distribution of exonic and intronic TP53 SNPs among observed CLL patients

\begin{tabular}{|c|c|c|c|c|c|c|c|}
\hline \multirow{2}{*}{$\begin{array}{l}\text { rs number, lo- } \\
\text { calization }\end{array}$} & \multirow{2}{*}{$\begin{array}{l}\text { Geno- } \\
\text { types }\end{array}$} & \multicolumn{3}{|c|}{ All CLL patients } & \multirow{2}{*}{$\begin{array}{c}\text { The main } \\
\text { group, } \\
\mathrm{n}(\%)\end{array}$} & \multirow{2}{*}{$\begin{array}{l}\text { The con- } \\
\text { trol gro- } \\
\text { up, } n(\%)\end{array}$} & \multirow[b]{2}{*}{ 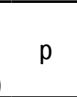 } \\
\hline & & $n(\%)$ & MAF & $p$ HWE & & & \\
\hline $\begin{array}{l}\text { rs } 1042522, \\
17: 7676154, \\
\text { p.P72R }\end{array}$ & $\begin{array}{l}\mathrm{Arg} / \mathrm{Arg} \\
\mathrm{Arg} / / \mathrm{Pro} \\
\text { Pro/Pro }\end{array}$ & $\begin{array}{c}115(48.7) \\
97(41.1) \\
24(10.2)\end{array}$ & 0.31 & 0.575 & $\begin{array}{c}49(46.2) \\
48(45.3) \\
9(8.5)\end{array}$ & $\begin{array}{l}66(50.8) \\
49(37.7) \\
15(11.5)\end{array}$ & 0.368 \\
\hline $\begin{array}{l}\text { rs } 1642785, \\
17: 7676483, \\
2-3 \text { intron }\end{array}$ & $\begin{array}{l}\mathrm{G} / \mathrm{G} \\
\mathrm{G} / \mathrm{C} \\
\mathrm{C} / \mathrm{C}\end{array}$ & $\begin{array}{l}119(50.4) \\
89(37.7) \\
28(11.9)\end{array}$ & 0.31 & 0.117 & $\begin{array}{l}56(52.8) \\
38(35.9) \\
12(11.3)\end{array}$ & $\left\{\begin{array}{l}63(48.5) \\
51(39.2) \\
16(12.3)\end{array}\right.$ & 0.567 \\
\hline $\begin{array}{l}\text { rs } 17878362, \\
3-4 \text { intron }\end{array}$ & $\begin{array}{l}\mathrm{A} 1 / \mathrm{A} 1 \\
\mathrm{~A} 1 / \mathrm{A} 2 \\
\mathrm{~A} 2 / \mathrm{A} 2\end{array}$ & $\begin{array}{c}167(70.8) \\
61(25.8) \\
8(3.4)\end{array}$ & 0.17 & 0.402 & $\begin{array}{c}77(72.7) \\
26(24.5) \\
3(2.8)\end{array}$ & $\begin{array}{c}90(69.2) \\
72(26.9) \\
5(3.9)\end{array}$ & 0.683 \\
\hline $\begin{array}{l}\text { rs } 2909430 \\
17: 7675327 \\
4-5 \text { intron }\end{array}$ & $\begin{array}{l}A / A \\
A / G \\
G / G\end{array}$ & $\begin{array}{c}178(75.4) \\
50(21.2) \\
8(3.4)\end{array}$ & 0.15 & 0.069 & $\begin{array}{c}80(75.5) \\
23(21.7) \\
3(2.8)\end{array}$ & $\begin{array}{c}98(75.4) \\
27(20.8) \\
5(4.8)\end{array}$ & 0.427 \\
\hline $\begin{array}{l}\text { rs12947788, } \\
\text { 17:7674109, } \\
\text { 7-8 intron }\end{array}$ & $\begin{array}{l}\mathrm{C} / \mathrm{T} \\
\mathrm{T} / \mathrm{T}\end{array}$ & $\begin{array}{c}195 \\
(82.6) \\
33(14.0) \\
8(3.4)\end{array}$ & 0.11 & 0.001 & $\begin{array}{c}86 \\
(81.2) \\
15(14.1) \\
5(4.7)\end{array}$ & $\begin{array}{c}109 \\
(83.8) \\
18(13.9) \\
3(2.3)\end{array}$ & 0.267 \\
\hline $\begin{array}{l}\text { rs12951053, } \\
\text { 17:7674089, } \\
\text { 7-8 intron }\end{array}$ & $\begin{array}{l}\mathrm{T} / \mathrm{G} \\
\mathrm{G} / \mathrm{G}\end{array}$ & $\begin{array}{c}195 \\
(82.6) \\
33(14.0) \\
8(3.4)\end{array}$ & 0.11 & 0.001 & $\begin{array}{c}86 \\
(81.2) \\
15(14.1) \\
5(4.7)\end{array}$ & $\begin{array}{c}109 \\
(83.8) \\
18(13.9) \\
3(2.3)\end{array}$ & 0.267 \\
\hline $\begin{array}{l}\text { rs17883323, } \\
\text { 17:7676301, } \\
3-4 \text { intron }\end{array}$ & $\begin{array}{l}C / A \\
A / A\end{array}$ & $\begin{array}{c}215 \\
(91.1) \\
20(8.5) \\
1(0.4)\end{array}$ & 0.05 & 0.479 & $\begin{array}{c}100 \\
(94.3) \\
6(5.7) \\
0\end{array}$ & $\begin{array}{c}115 \\
(88.5) \\
14(10.8) \\
1(0.7)\end{array}$ & 0.121 \\
\hline $\begin{array}{l}\text { rs } 17880847, \\
17: 7670579, \\
10-11 \text { intron }\end{array}$ & $\begin{array}{l}\mathrm{T} / \mathrm{T} \\
\mathrm{T} / \mathrm{A}\end{array}$ & $\begin{array}{c}230(97.5) \\
6(2.5)\end{array}$ & 0.014 & 0.751 & $\begin{array}{c}103(97.2) \\
3(2.8)\end{array}$ & $\begin{array}{c}127(97.7) \\
3(2.3)\end{array}$ & 0.867 \\
\hline $\begin{array}{l}\text { rs } 1800372, \\
17: 7674892, \\
\text { c.639A }>G \\
\text { (p.R213R) }\end{array}$ & $\mathrm{A} / \mathrm{A}$ & $\begin{array}{c}231(97.9) \\
5(2.1)\end{array}$ & 0.011 & 0.751 & $\begin{array}{c}103 \\
(97.2) \\
3(2.8)\end{array}$ & $\begin{array}{c}128 \\
(98.5) \\
2(1.5)\end{array}$ & 0.386 \\
\hline $\begin{array}{l}\text { rs 17880604, } \\
\text { 17:7674326, } \\
5-6 \text { intron }\end{array}$ & $\mathrm{C} / \mathrm{C}$ & $\begin{array}{c}231 \\
(97.9) \\
5(2.1)\end{array}$ & 0.011 & 0.751 & $\begin{array}{c}103 \\
(97.2) \\
3(2.8)\end{array}$ & $\begin{array}{c}128 \\
(98.5) \\
2(1.5)\end{array}$ & 0.286 \\
\hline $\begin{array}{l}\text { rs 1800370, } \\
17: 7676261\end{array}$ & $\mathrm{G} / \mathrm{G}$ & $\begin{array}{c}234 \\
(99.2)\end{array}$ & 0.004 & 0.999 & $\begin{array}{c}106 \\
(100.0)\end{array}$ & $\begin{array}{c}128 \\
(98.5)\end{array}$ & 0.205 \\
\hline $\begin{array}{l}\text { c.108G>A } \\
\text { (p.P36P) }\end{array}$ & $\mathrm{G} / \mathrm{A}$ & $2(0.8)$ & & & 0 & $2(1.5)$ & \\
\hline $\begin{array}{l}\text { rs } 150293825, \\
17: 7670695, \\
\text { c.1014C>T } \\
\text { (p.F338F) }\end{array}$ & $\mathrm{C} / \mathrm{C}$ & $\begin{array}{c}234 \\
(99.2) \\
2(0.8)\end{array}$ & 0.004 & 0.999 & $\begin{array}{c}106 \\
(100.0) \\
0\end{array}$ & $\begin{array}{c}128 \\
(98.5) \\
2(1.5)\end{array}$ & 0.205 \\
\hline $\begin{array}{l}\text { rs 146340390, } \\
17: 7674866, \\
\text { c.665C >T }\end{array}$ & $\mathrm{C} / \mathrm{C}$ & $\begin{array}{c}234 \\
(99.2) \\
2(0.8)\end{array}$ & 0.004 & 0.999 & $\begin{array}{c}104 \\
(98.1) \\
2(1.9)\end{array}$ & $\begin{array}{c}130 \\
(100.0) \\
0\end{array}$ & 0.127 \\
\hline $\begin{array}{l}\text { (p.P222L), } \\
\text { rs113530090, } \\
\text { 17:7675322, } \\
4-5 \text { intron }\end{array}$ & $\mathrm{T} / \mathrm{T}$ & $\begin{array}{c}245 \\
(99.2) \\
2(0.8)\end{array}$ & 0.004 & +0.751 & $\begin{array}{c}105 \\
(99.0) \\
1(1.0)\end{array}$ & $\begin{array}{c}129 \\
(99.2) \\
1(0.8)\end{array}$ & 0.965 \\
\hline $\begin{array}{l}\text { rs } 145153611, \\
\text { 17:7675337, } \\
4-5 \text { intron }\end{array}$ & $\mathrm{T} / \mathrm{T}$ & $\begin{array}{c}245 \\
(99.2) \\
2(0.8)\end{array}$ & 0.004 & 0.751 & $\begin{array}{c}105 \\
(99.0) \\
1(1.0)\end{array}$ & $\begin{array}{c}129 \\
(99.2) \\
1(0.8)\end{array}$ & 0.965 \\
\hline $\begin{array}{l}\text { rs539224556, } \\
17: 7670632, \\
\text { c.1077A>G } \\
\text { (p.P359P) }\end{array}$ & $\mathrm{A} / \mathrm{G}$ & $\begin{array}{c}235 \\
(96.6) \\
1(0.4)\end{array}$ & 0.002 & 0.751 & $\begin{array}{c}106 \\
(100.0) \\
0\end{array}$ & $\begin{array}{c}129 \\
(99.2) \\
1(0.8)\end{array}$ & 0.236 \\
\hline $\begin{array}{l}\text { 17:7674354, } \\
6-7 \text { intron }\end{array}$ & $\mathrm{C} / \mathrm{C}$ & $\begin{array}{c}235 \\
(96.6) \\
1(0.4)\end{array}$ & 0.002 & 0.751 & $\begin{array}{c}106 \\
(100.0) \\
0\end{array}$ & $\begin{array}{c}129 \\
(99.2) \\
1(0.8)\end{array}$ & 0.236 \\
\hline $\begin{array}{l}\text { rs } 373232559 \\
17: 7670453, \\
10-11 \text { intron }\end{array}$ & $\mathrm{G} / \mathrm{G}$ & $\begin{array}{c}235 \\
(96.6) \\
1(0.4)\end{array}$ & 0.002 & 0.751 & $\begin{array}{c}106 \\
(100.0) \\
0\end{array}$ & $\begin{array}{c}129 \\
(99.2) \\
1(0.8)\end{array}$ & 0.236 \\
\hline $\begin{array}{l}\text { rs } 45599946, \\
17: 7670455, \\
10-11 \text { intron }\end{array}$ & $\mathrm{C} / \mathrm{C}$ & $\begin{array}{c}235 \\
(96.6) \\
1(0.4)\end{array}$ & 0.002 & 0.751 & $\begin{array}{c}106 \\
(100.0) \\
0\end{array}$ & $\begin{array}{c}129 \\
(99.2) \\
1(0.8)\end{array}$ & 0.236 \\
\hline
\end{tabular}

asbestos-exposed non-small cell lung cancer and malignant pleural mesothelioma (asbestos-related cancer). Association between rs12951053 and ovarian cancer risk was found, and it was suggested that rs 12951053 is in weak linkage disequilibrium with SNPs affecting transcription factor binding sites [23]. 


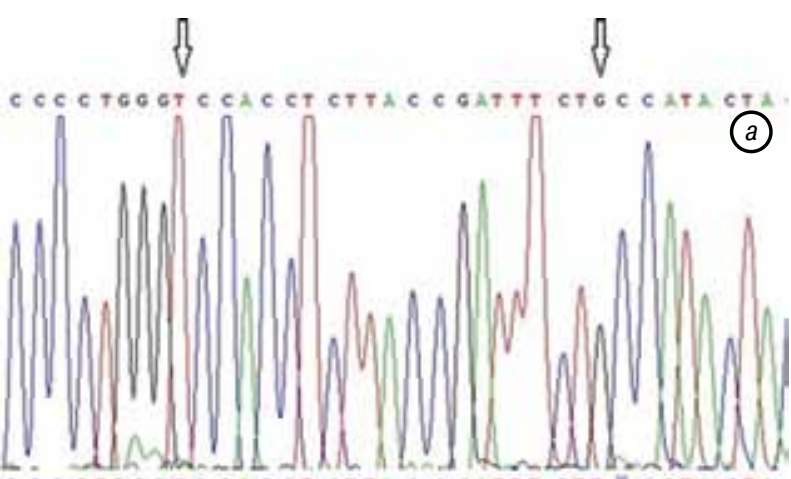

CCCCTCGGACCACCTCTTAC CGATTFCTHC CATA CFA
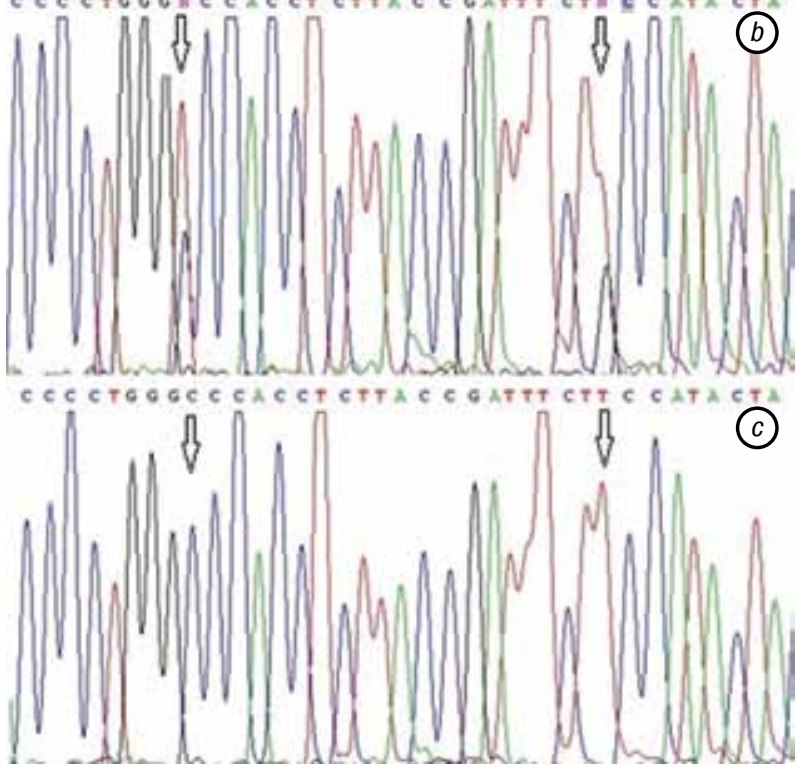

Fig. 1. Sanger sequencing raw data for $r s 12947788(C / T)$ and rs12951053 (T/G) TP53 polymorphisms: a) T/T, G/G; b) C/T, $\mathrm{T} / \mathrm{G} ; c) \mathrm{C} / \mathrm{C}, \mathrm{T} / \mathrm{T}$ genotypes. The positions of polymorphisms are indicated by arrows

Table 3. Distribution of rs 12947788 , rs 12951053 , and rs 146340390 TP53 SNPs among observed CLL patients comparing with healthy Caucasians (data from the 1000 Genomes Project)

\begin{tabular}{|c|c|c|c|c|c|c|}
\hline SNP & $\begin{array}{l}\text { Geno- } \\
\text { types }\end{array}$ & $\begin{array}{l}\text { The } \\
\text { main } \\
\text { group, } \\
\mathrm{n}(\%)\end{array}$ & $\begin{array}{l}\text { The } \\
\text { control } \\
\text { group, } \\
\mathrm{n}(\%)\end{array}$ & $\begin{array}{l}\text { Healthy } \\
\text { Cauca- } \\
\text { sians, } \\
\text { n (\%) }\end{array}$ & $\begin{array}{l}\text { IR-exposed } \\
\text { CLL patients } \\
\text { vs healthy } \\
\text { Caucasians }\end{array}$ & $\begin{array}{c}\text { IR non- } \\
\text { exposed } \\
\text { CLL patients } \\
\text { vs healthy } \\
\text { Caucasians }\end{array}$ \\
\hline rs12947788 & $\begin{array}{l}\mathrm{C} / \mathrm{C} \\
\mathrm{C} / \mathrm{T} \\
\mathrm{T} / \mathrm{T}\end{array}$ & $\begin{array}{c}86 \\
(81.2) \\
15 \\
(14.1) \\
5(4.7)\end{array}$ & $\begin{array}{c}109 \\
(83.8) \\
18 \\
(13.9) \\
3(2.3)\end{array}$ & $\begin{array}{c}412 \\
(81.9) \\
83 \\
(16.5) \\
8(1.6)\end{array}$ & 0.01 & 0.05 \\
\hline $\begin{array}{l}\text { Minor homo- } \\
\text { zygotes }\end{array}$ & & & & & 0.042 & 0.583 \\
\hline rs 129 & $\begin{array}{l}T / T \\
T / G \\
G / G\end{array}$ & $\begin{array}{c}86 \\
(81.2) \\
15 \\
(14.1) \\
5(4.7)\end{array}$ & $\begin{array}{c}109 \\
(83.8) \\
18 \\
(13.9) \\
3(2.3)\end{array}$ & $\begin{array}{c}412 \\
(81.9) \\
83 \\
(16.5) \\
8(1.6)\end{array}$ & 0.01 & 0.05 \\
\hline $\begin{array}{l}\text { Minor homo- } \\
\text { zygotes }\end{array}$ & & & & & 0.042 & 0.583 \\
\hline 390 & $\mathrm{C} / \mathrm{C}$ & $\begin{array}{c}104 \\
(98.1) \\
2(1.9) \\
\end{array}$ & $\begin{array}{c}130 \\
(100.0) \\
0\end{array}$ & $\begin{array}{c}4298 \\
(99.95) \\
2(0.05) \\
\end{array}$ & 0.0001 & 0.996 \\
\hline
\end{tabular}

Another nucleotide substitution, c. $665 \mathrm{C}>\mathrm{T}$ (rs146340390), was found only in the main group (Fig. 2). This substitution was identified as an extremely rare mutation in different solid tumors -8 of 29,893 cases, $0.026 \%$ (IARC TP53 database), and also as a very rare SNP -2 of 4300 cases among Americans of European descent, $0.047 \%$ (GO-ESP project; https://esp.gs.washington.edu/drupal). We considered c. $665 \mathrm{C}>\mathrm{T}$ substitution as SNP in our cases since in one patient it was found in DNA from the buccal mucosa as well as in tumor DNA (germline DNA sample was not available for the second patient). The frequency of rs 146340390 was higher in comparison with healthy persons (data of GO-ESP project). c. $665 \mathrm{C}>\mathrm{T}$ results in substitution of proline to leucine in position 222 (p.Pro222Leu) and significantly impaired p53 activity (23.96\% compared to wild type TP53).
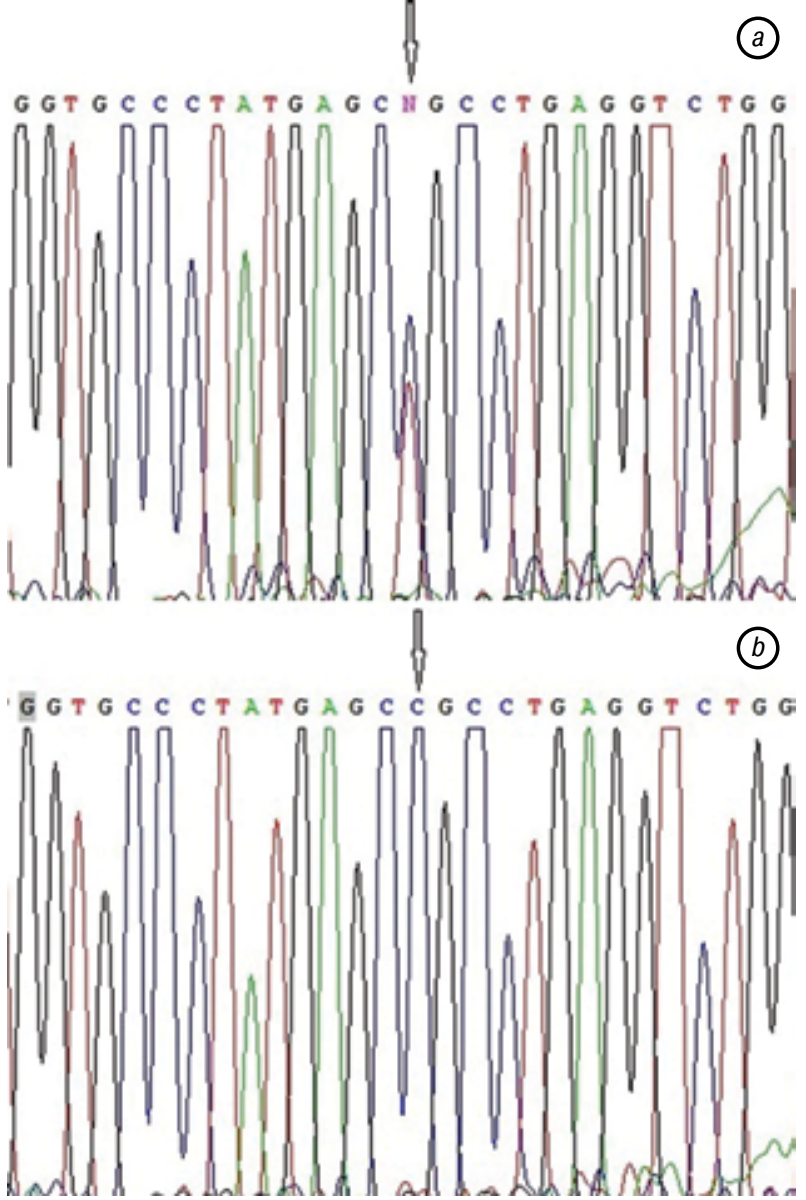

Fig. 2. Sanger sequencing raw data for rs 146340390 (substitution c.665C>T) of TP53: a) C/T genotype; b) C/C genotype

It is noteworthy that from $5 \mathrm{~T} / \mathrm{T}$ rs 12947788 and G/G rs12951053 homozygotes 3 cases were found in cleanup workers engaged in emergency works in $2^{\text {nd }}$ quarter (April-May) of 1986, one case in cleanup worker of 1987 , and one - in evacuee. Both patients with rs 146340390 (substitution c.665C $>$ T) were cleanup workers engaged in emergency works in $2^{\text {nd }}$ quarter of 1986. Doses of irradiation were not known in these patients, but the data on irradiation doses were available for other 18 cleanup workers engaged in emergency works in $2^{\text {nd }}$ quarter of 1986 (35.68 $\pm 8.53 \mathrm{cSv}$ ), 10 cleanup workers engaged in emergency works in other periods of 1986 (9.57 $\pm 3.43 \mathrm{cSv}), 7$ cleanup workers of 1987-1989 (5.73 $\pm 1.09 \mathrm{cSv}), 4$ evacuees $(4.76 \pm 0.35 \mathrm{cSv})$, and 7 inhabitants of radionuclide contaminated areas $(1.01 \pm 0.26 \mathrm{cSv})$. These data are in accordance with the data of International Program on the 
Health Effects of the Chernobyl Accident (IPHECA) [24]. According to them, the majority of cleanup workers of 1986 received the doses higher than $10 \mathrm{cSv}(80.0 \%)$, and absorbed dose for cleanup workers of 1986 averaged $31 \mathrm{cSv}$ ( $41 \mathrm{cSv}$ for cleanup workers engaged in emergency works in 26-30.04.1986, and $9.7 \mathrm{cSv}$ for those working in May-December, 1986). Thus, we may conclude that the frequencies of rs 12947788 , rs12951053, and rs 146340390 SNPs were the highest in the group of CLL patients who received the largest irradiation doses during Chornobyl nuclear power plant accident.

The frequency of the others SNPs in the main and the control groups did not differ from that in healthy European population (data not shown).

Exonic rs 1042522 was in linkage disequilibrium with intronic rs $1642785\left(d=0.908 ; r^{2}=0.8236 ; p<0.001\right)$, rs $17878362\left(d=0.733 ; r^{2}=0.2444 ; p<0.001\right)$, rs2909430 ( $\left.d=0.972 ; r^{2}=0.3698 ; p<0.001\right)$, rs12951053 ( $\left.d=0.85 ; r^{2}=0.1967 ; p<0.001\right)$, and rs $12947788\left(d=0.85 ; r^{2}=0.1967 ; p<0.001\right)$. Strong association was found between rs 12951053 and rs $12947788\left(d=0.793 ; r^{2}=0.40 ; p<0.001\right)$, and only 3 combinations of rs 12951053 and rs 12947788 genotypes were found $(82.0 \% \mathrm{CC} / \mathrm{TT} ; 14.6 \% \mathrm{CT} / \mathrm{CG}$, and $3.4 \% \mathrm{TT} / \mathrm{GG})$. These data were in accordance with previously reported results [15, 25-27].

A total of 17 different combinations of associated SNPs were found among observed CLL patients. The most CLL cases were homozygous for the major alleles of rs1042522, rs 1642785, rs 17878362, rs 17883323, rs2909430, rs12951053, and rs 12947788 (100 cases; $46.6 \%$ ). Previously it has been shown that combined G/G rs 1642785 and A1/A1 rs 17878362 alleles are associated with the highest basal and radiation-induced levels of fully spliced TP53 transcript and incompletely spliced transcript retaining intron 2 ( $p 5312$ ) [25]. The second most common combination (42 cases; $17.7 \%$ ) was Arg/Pro-G/C-A1/A2-C/C-A/G-C/C-T/T (indicated genotypes of listed above SNPs), and the third common combination was Arg/Pro-G/C-A1/A1-C/C-A/A-C/T$\mathrm{T} / \mathrm{G}$ (38 cases; $16.1 \%)$. The other haplotype frequencies ranged from 0.4 to $3.0 \%$. No differences were found between the main and the control groups ( $p=0.811$ ).

In summary, increased frequencies of $T / T$ rs $12947788+G / G$ rs12951053 homozygotes and rs 146340390 were found among IR-exposed CLL patients compared with healthy Europeans. These features were primarily typical for the most affected group of IR-exposed patients, namely, cleanup workers engaged in action in the $2^{\text {nd }}$ quarter of 1986 . These preliminary findings don't contradict the assumption on possible influence of IR on CLL development, and are in accordance with the data evidencing that cellular responses on IR are realized mainly through the p53-dependent pathway [28].

\section{REFERENCES}

1. Romanenko AY, Finch SC, Hatch M, et al. The Ukrainian-American study of leukemia and related disorders among
Chornobyl cleanup workers from Ukraine: III. Radiation risks. Radiat Res 2008; 170: 711-20.

2. Zablotska LB, Bazyka D, Lubin JH, et al. Radiation and the rick of chronic lymphocytic and other leukemias among Chornobyl cleanup workers. Environ Health Perspect 2013; 121: 59-65.

3. Bazyka D, Gudzenko N, Dyagil I, et al. Chronic lymphocytic leukemia in Chornobyl cleanup workers. Health Phys 2016; 111: 186-91.

4. Gudzenko N, Hatch M, Bazyka D, et al. Non-radiation risk factors for leukemia: a case-control study among Chornobyl cleanup workers in Ukraine. Environ Res 2015; 142: 72-6.

5. Lynce F, Isaacs C. How far do we go with genetic evaluation? Gene, panel, and tumor testing. Am Soc Clin Oncol Educ Book 2016; 35: e72-8.

6. Kleibl Z, Kristensen VN. Women at high risk of breast cancer: molecular characteristics, clinical presentation and management. Breast 2016; 28: 136-44.

7. Sugimura H. Susceptibility to human cancer: from the perspective of a pathologist. Pathol Int 2016; 66: 359-68.

8. Tian X, Dai S, Sun J, et al. Association between TP53 Arg72Pro polymorphism and leukemia risk: a metaanalysis of 14 case-control studies. Sci Rep 2016; 6: 24097.

9. Almeida BC, Kleine JP, Camargo-Kosugi CM, et al. Analysis of polymorphisms in codons 11, 72 and 248 of TP53 in Brazilian women with breast cancer. Genet Mol Res 2016; 15 (1): gmr7055.

10. Yuan $F$, Sun $R$, Chen $P$, et al. Combined analysis of pri-miR-34b/c rs4938723 and TP53 Arg72Pro with cervical cancer risk. Tumour Biol 2016; 37: 6267-73.

11. Chen $P$, Sun $R, P u Y$, et al. Pri-Mir-34b/C and $T P-53$ polymorphisms are associated with the susceptibility of papillary thyroid carcinoma: a case-control study. Medicine (Baltimore) 2015; 94: e1536.

12. Lui L, Wang K, Zhu ZM, Shao JH. Associations between P53 Arg72Pro and development of digestive tract cancers: a meta-analysis. Arch Med Res 2011; 42: 60-9.

13. Stacey $S N$, Sulem $P$, Jonasdottir A, et al. A germline variant in the TP53 polyadenylation signal confers cancer susceptibility. Nat Genet 2011; 43: 1098-103.

14. Andujar P, Pairon JC, Renier A, et al. Differential mutation profiles and similar intronic TP53 polymorphisms in asbestos-related lung cancer and pleural mesothelioma. Mutagenesis 2013; 28: 323-31.

15. Voropaeva EN, Voevoda MI, Pospelova TI, Maksimov VN. Linkage disequilibrium and haplotypes of rs 1042522 , rs1625895 and rs17878362 gene TP53 markers in patients with diffuse large B-cell lymphoma. Mol Biol (Mosk) 2014; 48: 763-70 (in Russian).

16. Sagne C, Marcel V, Amadou A, et al. A meta-analysis of cancer risk associated with the TP53 intron 3 duplication polymorphism (rs17878362): geographic and tumor-specific effects. Cell Death Dis 2013; 4: e492.

17. Kochethu G, Delgado J, Pepper C, et al. Two germ line polymorphisms of the tumour suppressor gene p53 may influence the biology of chronic lymphocytic leukemia. Leuk Res 2006; 30: 1113-8.

18. Dong HJ, Fang C, Wang L, et al. TP53 Pro72 allele potentially increases the poor prognostic significance of TP53 mutations in chronic lymphocytic leukemia. Med Oncol 2014; 31: 908.

19. Sturm I, Bosanquet AG, Hummel M, et al. In B-CLL, the codon 72 polymorphic variants of $\mathrm{p} 53$ are not related to drug resistance and disease prognosis. BMC Cancer 2005; 5: 105.

20. Binet JL, Auquier A, Dighiero G, et al. A new prognostic classification of chronic lymphocytic leukemia derived from a multivariate survival analysis. Cancer 1981; 48: 198-205. 
21. Rai KR, Sawitzky A, Cronkite EP, et al. Clinical staging of chronic lymphocytic leukemia. Blood 1975; 46: 219-34.

22. Bilous NI, Abramenko IV, Chumak AA, et al. TP53 codon 72 single nucleotide polymorphism in chronic lymphocytic leukemia. Exp Oncol 2014; 36: 258-61.

23. Schildkraut JM, Iversen ES, Wilson MA, et al. Association between DNA damage response and repair genes and risk of invasive serous ovarian cancer. PLoS One 2010; 5: e10061.

24. World Health Organization. Health consequences of the Chernobyl accident. Results of the IPHECA pilot projects and related national programmes. Scientific report. Moscow: Vidar Ltd, 1996. 559 p. (in Russian).

25. Perriaud L, Marcel V, Sagne C, et al. Impact of G-quadruplex structures and intronic polymorphisms rs 17878362 and rs1642785 on basal and ionizing radiation-induced expression of alternative p53 transcripts. Carcinogenesis 2014; 35: $2706-15$.

26. Sailaja K, Rao VR, Yadav S, et al. Intronic SNPs of TP53 gene in chronic myeloid leukemia: impact on drug response. J Nat Sci Biol Med 2012; 3: 182-5.

27. Pangilinan F, Geiler K, Dolle J, et al. Construction of a high resolution linkage disequilibrium map to evaluate common genetic variation in TP53 and neural tube defect risk in an Irish population. Am J Med Genet A 2008; 146A: 2617-25.

28. Cao L, Kawai H, Sasatani M, et al. A novel ATM/ TP53/p21-mediated checkpoint only activated by chronic $\gamma$-irradiation. PloS One 2014; 9: e104279. 